\title{
MICROSTRUCTURE AND MECHANICAL PROPERTIES OF WIRE ARC ADDITIVE-MANUFACTURING HIGH-CARBON CHROMIUM BEARING STEEL
}

\author{
MIKROSTRUKTURA IN MEHANSKE LASTNOSTI Cr-Mo \\ LEŽAJNEGA JEKLA IZDELANEGA Z DODAJNO TEHNOLOGIJO \\ NA OSNOVI ŽIČNEGA OBLOKA
}

\author{
Wenjie Zhang ${ }^{1}$, Weining Lei ${ }^{1,2 *}$, Yang Zhang ${ }^{1,2}$, Xiao Liu ${ }^{1,2}$ \\ ${ }^{1}$ School of Materials Engineering, Jiangsu University of Technology, No. 1801 Zhongwu Road, Changzhou, Jiangsu 213001, China \\ ${ }^{2}$ Key Laboratory of Advanced Materials Design and Additive Manufacturing of Jiangsu Province, No. 1801 Zhongwu Road, Changzhou, \\ Jiangsu 213001, China
}

Prejem rokopisa - received: 2019-07-22; sprejem za objavo - accepted for publication: 2019-10-11

Wire arc additive-manufacturing technology (WAAM) was conducted successfully on a high-carbon chromium bearing steel with an ER55-Ni welding wire and a GCr18Mo substrate. It is found that the microstructure of the cross-section of the WAAM sample is divided into three parts, i.e., the deposition layer, the transition layer and the substrate. The microstructure of the deposition layer mainly consists of needle-like tempered martensite and cementite, with a small quantity of ferrite. The transition zone is composed of coarse bainite and ferrite. In the deposition layer, the hardness gradually decreases from the top to the root, and the hardness of the transition layer is close to $350 \mathrm{HV}$. The arc-cladding sample exhibits a higher yield strength and tensile strength but lower elongation than the substrate sample. The necking is formed and a failure occurs at the transition layer of the WAAM sample. The maximum depth values of wear scars on WAAM and substrate samples are close to each other The wear is more uniform on the WAAM sample but the cross-sectional area of its wear scar is larger than that of the substrate sample. The wear resistance of the WAAM sample is lower than that the substrate sample, which is mainly attributed to the low hardness of the WAAM sample.

Keywords: additive manufacturing technology, high-carbon chromium bearing steel, microstructure, mechanical properties

Avtorji so uspešno nanesli prevleko na podlago iz visoko ogljičnega Cr-Mo ležajnega jekla GCr18Mo z dodajalno tehnologijo na osnovi obloka (WAAM) varilne ER55-Ni žice. Ugotovili so, da je mikrostruktura v preseku WAAM-vzorca razdeljena na tri dele. Ti so: na nanešeno (navarjeno) plast, prehodni pas in podlago. Mikrostruktura na podlago nanešene plasti je v glavnem sestavljena iz igličastega popuščenega martenzita in cementita z majhno vsebnostjo ferita. Prehodna cona je sestavljena iz grobega bainita in ferita. Trdota nanešene plasti se postopno zmanjšuje od vrha proti podlagi in v povprečju znaša okoli $350 \mathrm{HV}$. Obločno nanešena plast ima višjo mejo plastičnosti toda manjši raztezek kot podlaga. Med nateznim preizkusom je prišlo do zoževanja (nastanka vratu) na WAAM-vzorcu in do njegove porušitve je prišlo v prehodni coni. Maksimalna globina raz nastalih $\mathrm{s}$ preizkusi obrabe je približno enaka na WAAM-vzorcu in vzorcu iz podlage. Obraba je bolj enakomerna na WAAM-vzorcu vendar je v preseku nastale večje število raz zaradi obrabe kot tiste, ki so nastale na podlagi. Odpornost proti obrabi WAAM-vzorca je manjša od tiste na podlagi, kar avtorji v glavnem pripisujejo nižji trdoti WAAM-vzorca.

Ključne besede: dodajna tehnologija, nanos prevleke na osnovi obloka varilne žice, kromovo ležajno jeklo z visoko vsebnostjo ogljika, mikrostruktura, mehanske lastnosti

\section{INTRODUCTION}

Additive-manufacturing (AM) technology is a bottom-up and layer-by-layer manufacturing method, which has the advantages of a fast forming speed, high utilization of the material and high production efficiency. ${ }^{1-2}$ Over the years, AM researches have been focused on improving the mechanical properties of forming components so that they can be used directly. As one kind of the AM technology, wire arc additivemanufacturing technology (WAAM) takes arc as the heat source and inert gases (such as Ar) as the protection atmosphere. ${ }^{3-4}$ By layer-by-layer manufacturing, near-net shape forming is achieved in WAAM. ${ }^{5-6}$ The direct-form-

*Corresponding author's e-mail:

leiweining@jsut.edu.cn (Weining Lei) ing technology based on an arc heat source has the advantages of low production costs and good mechanical properties and has been widely used in various industrial fields, such as the automobile industry, aerospace, food and medical treatment. ${ }^{7-8}$

In recent years, WAAM has attracted great attention with the formation and repair of various kinds of metallic materials, including $\mathrm{Mg}$ alloys, $\mathrm{Al}$ alloys and $\mathrm{Ti}$ alloys. ${ }^{9-10}$ For example, Y. Y. Guo et al. ${ }^{11}$ studied the microstructure and tensile properties of an AZ80M Mg alloy made with WAAM, and the results showed that the microstructure of the WAAM AZ80M alloy was inhomogeneous, containing micro-defects, which influenced the mechanical properties. T. T. Wang et al. ${ }^{12}$ studied the microstructure and tensile properties of WAAM die-steel components made of an $\mathrm{H} 13$ steel welding wire, and the 
W. ZHANG et al.: MICROSTRUCTURE AND MECHANICAL PROPERTIES OF WIRE ARC ADDITIVE-MANUFACTURING ...

Table 1: Chemical compositions of the ER55-Ni welding wire and GCr18Mo bearing steel used in this study, ( $w \%$ C)

\begin{tabular}{|c|c|c|c|c|c|c|c|c|c|}
\hline Alloys & $\mathrm{C}$ & $\mathrm{Si}$ & $\mathrm{Mn}$ & $\mathrm{P}$ & $\mathrm{Ni}$ & $\mathrm{Cr}$ & Mo & $\mathrm{Cu}$ & $\mathrm{Fe}$ \\
\hline ER55-Ni2 & $\leq 0.12$ & 0.4 & $\leq 1.25$ & $\leq 0.025$ & $0.80 \approx 1.10$ & $\leq 0.15$ & $\leq 0.35$ & $\leq 0.35$ & Bal. \\
\hline GCr18Mo & 0.9 & 0.2 & 0.25 & 0.02 & 0.25 & 1.65 & 0.20 & 0.25 & Bal. \\
\hline
\end{tabular}

results showed that the components were well formed with a uniform hardness distribution.

High-carbon chromium bearing steel is widely used as a rolling-bearing material, due to its high toughness, good wear resistance, suitable elasticity, good corrosion resistance and good machinability. ${ }^{13-14}$ However, the repair of high-carbon chromium bearing steel in a service environment is difficult once damage occurs. So far, there has been little research on the AM of high-carbon chromium bearing steel. In this paper, an ER55-Ni welding wire was used for WAAM on a GCr18Mo substrate, which was a typical bearing steel. The microstructure, mechanical properties and wear behavior of the WAAM sample were investigated. The reasons for the difference between the WAAM sample and the substrate were analyzed.

\section{EXPERIMENTAL PART}

\subsection{Materials}

The chemical compositions of the ER55-Ni welding wire and GCr18Mo bearing steel used in this study are listed in Table 1. The diameter of the ER55-Ni welding wire was $1.2 \mathrm{~mm}$ and the dimensions of the GCr18Mo bearing-steel plate was $200 \mathrm{~mm} \times 200 \mathrm{~mm} \times 14 \mathrm{~mm}$.

\subsection{WAAM process}

A schematic of the WAAM process is shown in Figure 1. A tungsten-inert-gas (TIG) welding machine and alternating-current power supply were used in this study. The welding parameters used in this study are listed in Table 2. The length of the weld bead deposited on the substrate is $150 \mathrm{~mm}$ and 12 layers were deposited. The final weld-bead height was about $20 \mathrm{~mm}$.

Table 2: WAAM processing parameters used in this study

\begin{tabular}{|l|c|}
\hline \multicolumn{1}{|c|}{ Processing parameter } & Value \\
\hline Welding current $(\mathrm{A})$ & 190 \\
\hline Wire feed speed $(\mathrm{mm} / \mathrm{s})$ & 3.2 \\
\hline Travel speed $(\mathrm{mm} / \mathrm{s})$ & 4 \\
\hline Wire feeding angle $\left({ }^{\circ}\right)$ & 55 \\
\hline Tungsten electrode diameter $(\mathrm{mm})$ & 3.2 \\
\hline Flow rate of $99.99-\%$ argon shielding gas $(\mathrm{L} / \mathrm{s})$ & 1.7 \\
\hline Interval time between two layers $(\mathrm{s})$ & 30 \\
\hline
\end{tabular}

\subsection{Testing and characterization}

The cross-section specimens of the WAAM sample were cut with wire-cut electrical-discharge machining and treated with the standard metallographic preparation method. The microstructure was observed with a light

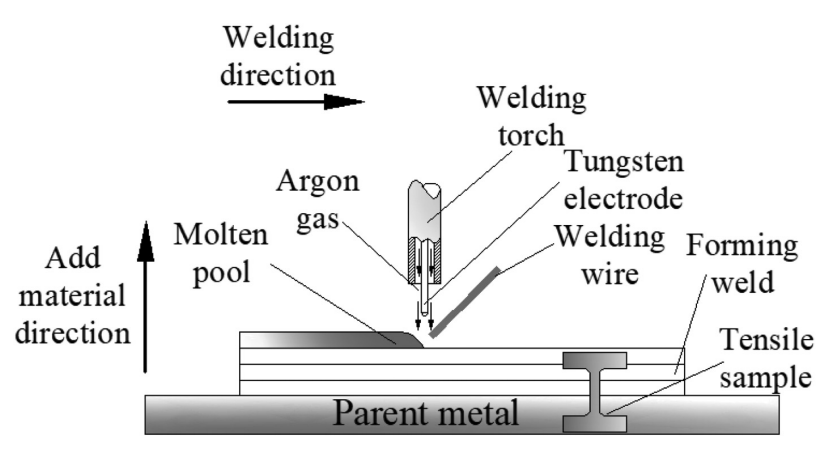

Figure 1: Schematic presentation of WAAM

microscope (LM) and scanning electron microscope (SEM). The hardness of the specimens was measured with a digital microhardness tester (HVS-1000B). The sampling place of the tensile specimens is shown in Figure 1; the gauge dimensions were $10 \mathrm{~mm}$ in length, 3 $\mathrm{mm}$ in width and $1 \mathrm{~mm}$ in thickness. A tensile test at room temperature was conducted with an electronic universal tensile-testing machine (WDW3200) and the tensile rate was $2 \mathrm{~mm} / \mathrm{min}$. In the tensile test, two groups of samples were drawn and one set of data was selected. The strain evolution during the tensile test was characterized with a digital image correlation (DIC) system. The wear behavior was tested with a friction-wear tester (Nanovea Tribometer). A micro-profilometer (Nanovea PS50) and SEM were used to observe the surface morphology of the tensile specimens and wear marks.

\section{RESULTS AND DISCUSSION}

\subsection{Microscopy}

As shown in Figure 2a, the microstructure of the cross-section is divided into three parts, i.e., the deposition layer, transition layer and substrate. As shown in Figure 2b, the microstructure of the deposition layer mainly consists of tempered martensite and cementite, with a small quantity of ferrite. The morphology of tempered martensite exhibits a fine needle-like pattern, which grows irregularly in multiple directions. It can be seen from the SEM image of the deposition layer in Figure 2c that some carbides are distributed at the grain boundaries and in the tempered-martensite matrix. Figure 2d shows the microstructure of the transition zone, which is composed of coarse bainite and ferrite. Due to the thermal-exposure influence during WAAM, microcracks were formed in the transition zone and these microcracks range in length from $40 \mu \mathrm{m}$ to $50 \mu \mathrm{m}$, leading to a great reduction in both plasticity and toughness of the region. 


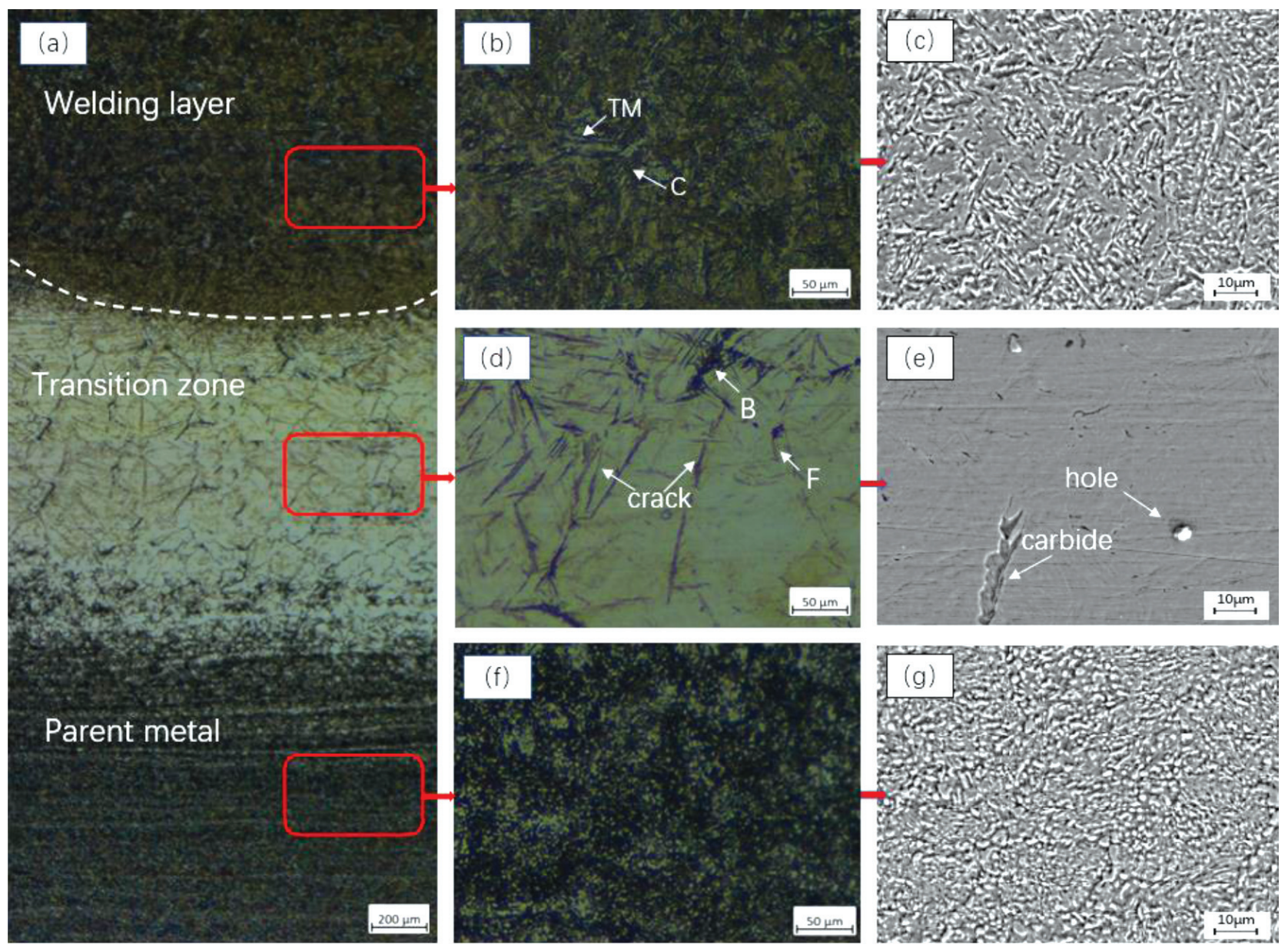

Figure 2: Microstructure of the cross-section of a WAAM sample observed with LM and SEM: a) junction of WAAM, b), c) welding layer, d), e) transition zone f), g) parent metal

As shown in Figures 2d and 2e, the microstructure of the transition zone is different from the deposition layer or the substrate. There is an obvious difference in the chemical composition between the welding wire and the substrate. High-carbon steel usually exhibits high crack sensitivity. Due to the high energy density and fast cooling during the WAAM process, hardening and cracking are easy to occur in the transition zone. In addition, the heat exposure of bainite results in the precipitation and coarsening of carbides. Figure $2 \mathbf{f}$ shows the microstructure of the substrate, which is composed of fine-grained low bainite and cementite. The SEM image in Figure $\mathbf{2 g}$ shows that the carbides are uniformly distributed in the GCr18Mo substrate.

\subsection{Hardness}

Figure 3 shows the hardness distribution from the top to the root at the center of the weld. According to the hardness-distribution curve, the hardness gradually decreases from the top to the root, and the hardness of the transition layer is close to $350 \mathrm{HV}$. As the welding joint is subjected to several thermal cycles, the martensite gradually changes into tempered martensite with a relatively low hardness. Since the chemical composition of the deposition layer is different from that of the substrate, its amount of carbide is lower than that of the substrate. Meanwhile, coarse grains are formed in the

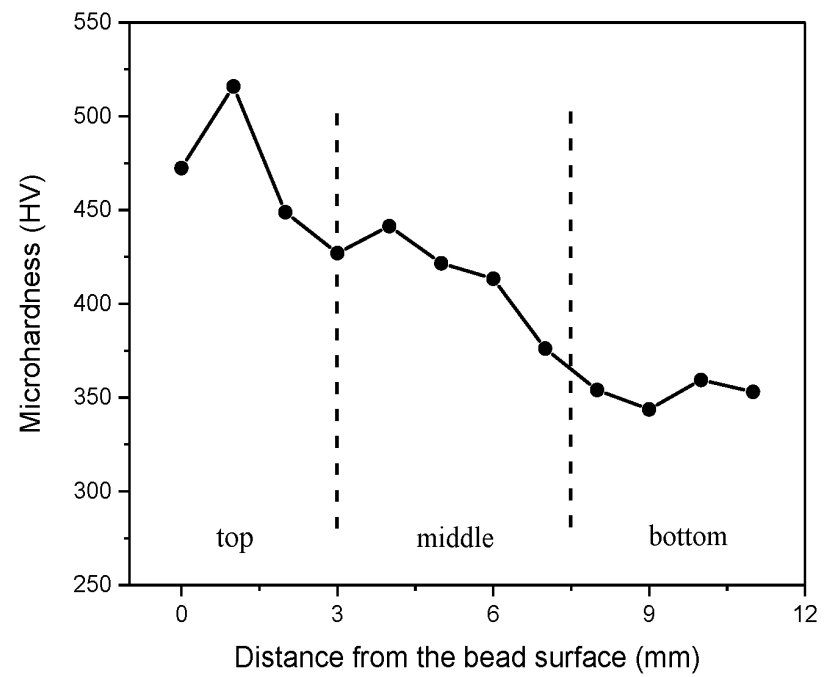

Figure 3: Hardness distribution from the top to the root at the center of the weld 
deposition layer due to the thermal exposure. As a result, the hardness of the deposition layer is lower than that of the substrate.

\subsection{Tensile properties}

The specific data for the tensile properties are summarized in Table 3. According to the tensile-test results, the WAAM sample exhibits higher yield strength (YS) and ultimate tensile strength (UTS) but lower elongation (EL) than the substrate sample. The YS and UTS of the WAAM sample reach $622 \mathrm{MPa}$ and 998 $\mathrm{MPa}$, higher by $102 \%$ and $70 \%$ than the substrate sample, respectively, while its EL is $20 \%$, which is $46 \%$ higher than that of the substrate sample.

Table 3: Specific data for the tensile properties

\begin{tabular}{|l|c|c|c|}
\hline \multicolumn{1}{|c|}{ Material } & YS/MPa & UTS/MPa & Elongation/\% \\
\hline Weld & 622 & 998 & 20 \\
\hline Parent metal & 308 & 588 & 37 \\
\hline
\end{tabular}

Figure 4 shows images of the dynamic-failure process of the tensile test obtained with the high-speed digital image correlation (DIC) method. As shown in Figure 4, there is an obvious neck shrinkage in both specimens after the tensile test, which indicates a ductile fracture in both the WAAM and substrate sample. The three recording moments during the tensile test are the initial moment, the intermediate moment and the near-failure moment, respectively. It can be seen that, at the initial moment, the axial strain field in the gauge part of both the WAAM and substrate sample is uniform and there is no obvious local strain. At the intermediate moment, a local strain is observed and obvious necking is seen in the WAAM sample. The necking is located at the transition layer.
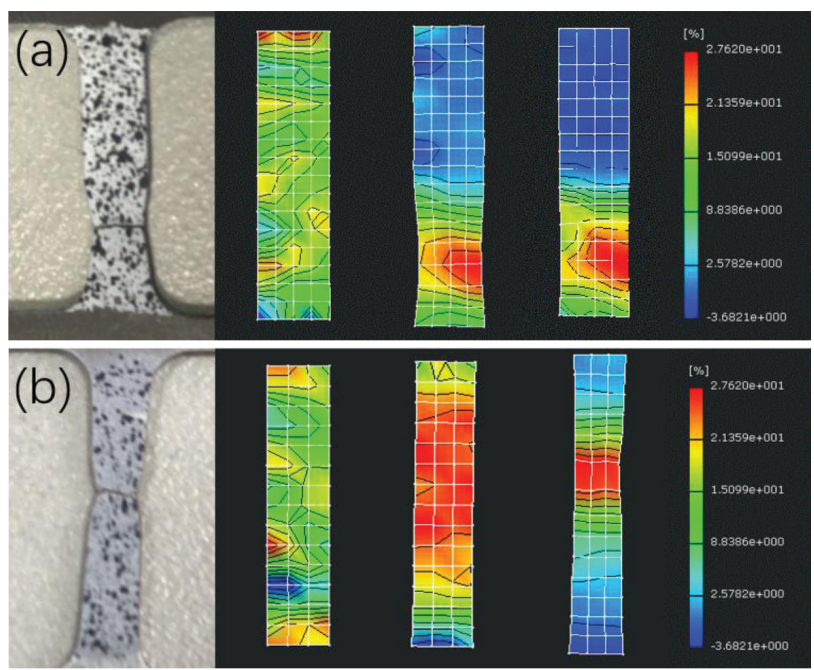

Figure 4: Images of the dynamic failure process of the tensile test obtained with the high-speed digital image correlation (DIC) method: a) substrate sample, b) WAAM sample
During the welding process, the fiber region in the interface between the cladding layer and the substrate undergoes a strong plastic deformation. This plastic deformation not only leads to an increase in the macroscopic strength of the sample, but also increases the overall microhardness of different regions and reduces the toughness. As for the substrate sample, there is still no obvious strain concentration. At the nearfailure moment, the strain distribution in the WAAM sample shows a little difference compared to the intermediate moment. The necking is formed and the failure occurs at the transition layer. As for the substrate sample, the strain concentration is observed at the near-failure moment and the corresponding necking and failure occur.

\subsection{Wear behavior}

Figure 5 shows a 3D wear scar and cross-sectional images of the WAAM and substrate sample. The maximum depth, cross-sectional area and wear rate calculated according to the cross-sectional images are shown in
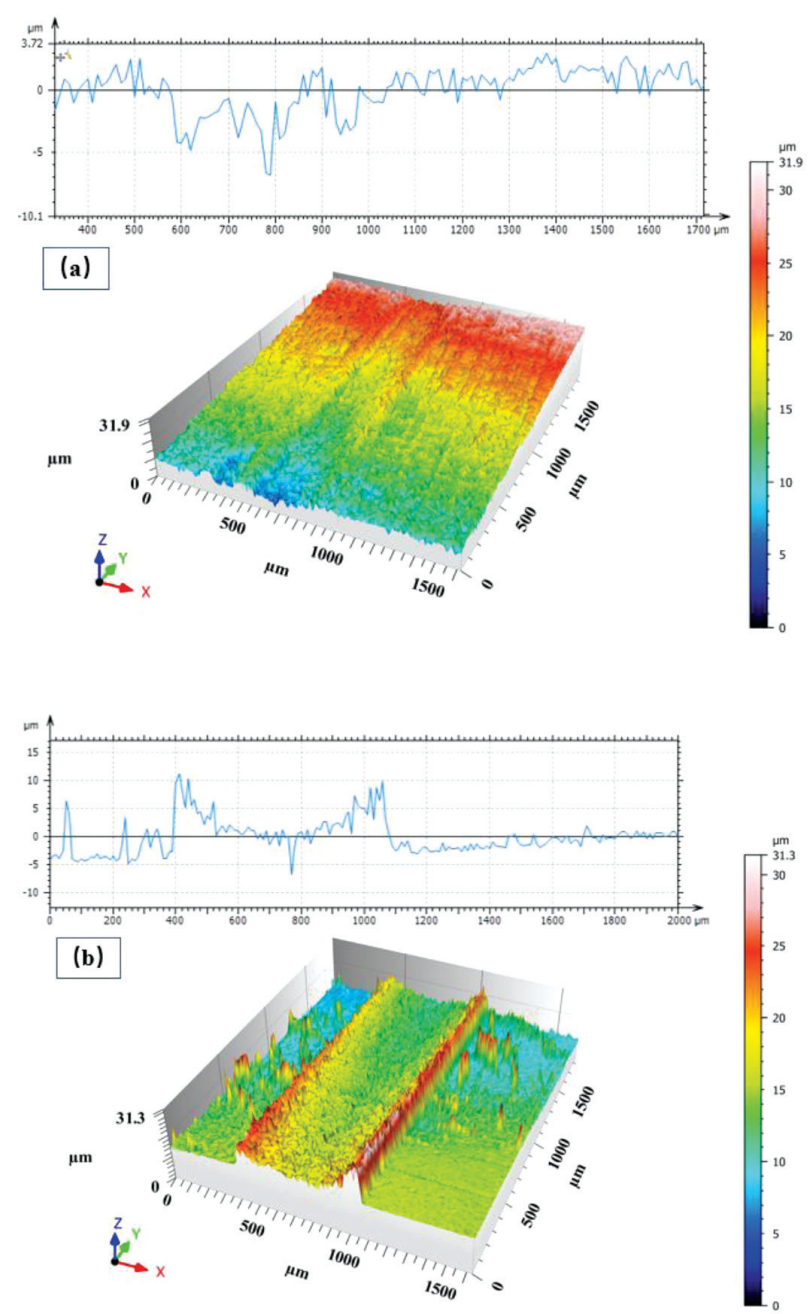

Figure 5: 3D wear scar and cross-section images of the WAAM and substrate samples: a) substrate sample, b) WAAM sample 
Table 5. It can be seen that the maximum depths of the wear scars in the WAAM and substrate sample are close to each other. The wear is more uniform on the WAAM sample but its cross-sectional area of the wear scar is larger than that of the substrate sample. The wear rate of the WAAM sample is $26.42 \mathrm{~mm}^{3} /(\mathrm{N} \cdot \mathrm{m})$, while the wear rate of the substrate sample is only $8.33 \mathrm{~mm}^{3} /(\mathrm{N} \cdot \mathrm{m})$. This shows that the wear resistance of the WAAM sample is lower than that of the substrate sample, which is mainly attributed to the low hardness of the WAAM sample. According to Archard's law, materials with high hardness always exhibit low wear rate and good wear resistance. ${ }^{15-16}$

Table 4: Wear results for the WAAM and substrate samples

\begin{tabular}{|c|c|c|c|}
\hline Materials & $\begin{array}{c}\text { Maximum } \\
\text { wear depth/ } \\
\text { mm }\end{array}$ & $\begin{array}{c}\text { Cross-sectional } \\
\text { area of wear } \\
\text { marks/mm }\end{array}$ & $\begin{array}{c}\text { Wear rate } \\
\mathrm{mm}^{3} /(\mathrm{N} \cdot \mathrm{m})\end{array}$ \\
\hline $\begin{array}{c}\text { Substrate } \\
\text { sample }\end{array}$ & $7.6 \times 10^{-3}$ & $8.33 \times 10^{-4}$ & 8.33 \\
\hline $\begin{array}{c}\text { WAAM } \\
\text { sample }\end{array}$ & $7.22 \times 10^{-3}$ & $2.642 \times 10^{-3}$ & 26.42 \\
\hline
\end{tabular}

WAAM is applied to high-carbon steel. It takes about $12 \mathrm{~min}$ to form a cladding layer with a thickness of 20 $\mathrm{mm}$ and a length of $15 \mathrm{~cm}$, which enables rapid additive manufacturing. As shown in Figure 2, there are significant differences between the microstructures of the deposition layer, transition layer and substrate. During a WAAM process, the transition zone is subjected to the arc heat for several times and it is seriously affected by it, which results in a strong plastic deformation occurring in the fiber zone of the interface. As the height of the deposition layer gradually increases during the WAAM process, the heat dissipation and heat accumulation change. ${ }^{17,18}$ The heat-dissipation speed of the deposition layer slows down along the substrate and the temperature gradient gradually decreases along the vertical direction. The microstructure at the bottom of the deposition layer changes from martensite to tempered martensite, and the grain size is slightly larger than that of the substrate.

As shown in Figure 3, as the temperature gradient decreases, the grains grow coarse and the hardness is decreased. The hardness usually decreases as the grain size is increased. The hardness at the top of the deposition layer is the highest and close to that of the substrate. The microstructure evolution of the transition layer inevitably influences the tensile properties of the WAAM sample. The stress concentration and fracture appear in the transition layer, and the bonding between deposition layers is good. During a tensile test, a crack initiated at the transition layer is continuously expanded by the stress, resulting in a deteriorative elongation. ${ }^{19,20}$ The research on the WAAM of high-carbon steel is still new. For this reason, it is necessary to modify the test procedure, including the preheating of the substrate before the test and annealing after WAAM to reduce the residual stress and improve the mechanical properties.

\section{CONCLUSIONS}

In this paper, the WAAM process was successfully conducted on a high-carbon chromium bearing steel with an ER55-Ni welding wire and GCr18Mo substrate. The microstructure, mechanical properties and wear behavior of the WAAM sample were investigated. The main conclusions are as follows:

1) The microstructure of the cross-section of the WAAM sample is divided into three parts, i.e., the deposition layer, transition layer and substrate. The microstructure of the deposition layer mainly consists of needle-like tempered martensite and cementite, with a small quantity of ferrite. The transition zone is composed of coarse bainite and ferrite.

2) For the deposition layer of the WAAM sample, the hardness gradually decreases from the top to the root, and the hardness of the transition layer is close to 350 HV. The WAAM sample exhibits higher YS and UTS but lower EL than the substrate sample.

3) The maximum depths of the wear scars in the WAAM sample and substrate sample are close to each other. The wear of the WAAM sample is more uniform, but its cross-sectional area of the wear scar is larger than that of the substrate sample. The wear resistance of the WAAM sample is lower than that of the substrate sample.

\section{Acknowledgment}

This research was funded by the National Natural Science Foundation of China (No. 51275222), Major Project of the Natural Science Foundation from the Postgraduate Research \& Practice Innovation Program of the Jiangsu Province (No. SJCX18_1065).

\section{REFERENCES}

${ }^{1}$ L. L. Wang, J. Xue, Q. Wang, Correlation between arc mode, microstructure, and mechanical properties during wire arc additive manufacturing of $316 \mathrm{~L}$ stainless steel, Mater. Sci. Eng. A, 751 (2019), 183-190, doi:10.1016/j.msea.2019.02.078

${ }^{2}$ Z. W. Qi, B. J. Qi, B. Q. Cong, H. Y. Sun, G. Zhao, J. L. Ding, Microstructure and mechanical properties of wire + arc additively manufactured 2024 aluminum alloy components: As-deposited and post heat-treated, J. Manuf. Process., 40 (2019), 27-36, doi:10.1016/j.jmapro.2019.03.003

${ }^{3}$ D. Herzog, V. Seyda, E. Wycisk, C. Emmelmann, Additive manufacturing of metals, Acta Mater., 117 (2016), 371-392, doi:10.1016/j.actamat.2016.07.019

${ }^{4}$ G. Marinelli, F. Martina, H. Lewtas, D. Hancock, S. Mehraban, N. Lavery, Microstructure and thermal properties of unalloyed tungsten deposited by Wire + Arc Additive Manufacture, J. Nucl. Mater., 522 (2019), 45-53, doi:10.1016/j.jnucmat.2019.04.049

${ }^{5}$ S. Ríos, P. A. Colegrove, F. Martina, S. W. Williams, Analytical process model for wire + arc additive manufacturing, Additive Manufacturing, 21 (2018), 651-657, doi:10.1016/j.addma.2018. 04.003

${ }^{6}$ P. C. Priarone, G. Campatelli, F. Montevecchi, G. Venturini, A modelling framework for comparing the environmental and economic performance of WAAM-based integrated manufacturing and 
machining, CIRP Annals, 68 (2019) 1, 37-40, doi:10.1016/j.cirp. 2019.04.005

${ }^{7}$ A. Busachi, J. Erkoyuncu, P. Colegrove, F. Martina, J. Ding, Designing a WAAM Based Manufacturing System for Defence Applications, Procedia CIRP, 37 (2015), 48-53, doi:10.1016/j.procir. 2015.08.085

${ }^{8}$ H. Attar, M. J. Bermingham, S. Ehtemam-Haghighi, A. DehghanManshadi, D. Kent, Evaluation of the mechanical and wear properties of titanium produced by three different additive manufacturing methods for biomedical application, Mater. Sci. Eng. A, 760 (2019), 339-345, doi:10.1016/j.msea.2019.06.024

${ }^{9}$ J. Wang, Z. X. Pan, D. Cuiuri, H. J. Li, Phase constituent control and correlated properties of titanium aluminide intermetallic alloys through dual-wire arc additive manufacturing, Mater. Lett., 242 (2019), 111-114, doi:10.1016/j.matlet.2019.01.112

${ }^{10}$ E. M. Ryan, T. J. Sabin, J. F. Watts, M. J. Whiting, The influence of build parameters and wire batch on porosity of wire and arc additive manufactured aluminium alloy 2319, J. Mater. Process. Technol., 262 (2018), 577-584, doi:10.1016/j.jmatprotec.2018.07.030

${ }^{11}$ Y. Y. Guo, H. H. Pan, L. B. Ren, G. F. Quan, Microstructure and mechanical properties of wire arc additively manufactured AZ80M magnesium alloy, Materials Letters, 247 (2019), 4-6, doi:10.1016/ j.matlet.2019.03.063

${ }^{12}$ T. T. Wang, Y. B. Zhang, Z. H. Wu, C. W. Shi, Microstructure and properties of die steel fabricated by WAAM using H13 wire, Vacuum, 149 (2018), 185-189, doi:10.1016/j.vacuum.2017.12.034

${ }^{13}$ F. Zhang, Z. N. Yang, Development of and Perspective on High-Performance Nanostructured Bainitic Bearing Steel, Engineering, 5 (2019) 2, 319-328, doi:10.1016/j.eng.2018.11.024
${ }^{14}$ A. Ascari, A. Fortunato, Nanosecond pulsed laser welding of high carbon steels, Opt. Lasers Eng., 56 (2014), 25-34, doi:10.1016/ j.optlastec.2013.07.016

${ }^{15}$ L. Zhen, J. B. Wang, J. J. Lu, J. H. Meng, Tribological characteristics of electroless Ni-P-MoS2 composite coatings at elevated temperatures, Appl. Surf. Sci., 264 (2013), 516-521, doi:10.1016/j.apsusc. 2012.10.055

${ }^{16} \mathrm{M}$. Grandin, U. Wiklund, Friction, wear and tribofilm formation on electrical contact materials in reciprocating sliding against silvergraphite, Wear, 302 (2013) 1-2, 1481-1491, doi:10.1016/j.wear. 2013.02.007

${ }^{17}$ Z. Q. Hu, X. P. Qin, T. Shao, Welding Thermal Simulation and Metallurgical Characteristics Analysis in WAAM for 5CrNiMo Hot Forging Die, Procedia Engineering, 207 (2017), 2203-2208, doi:10.1016/j.proeng.2017.10.982

${ }^{18}$ F. Hejripour, F. Binesh, M. Hebel, D. K. Aidun, Thermal modeling and characterization of wire arc additive manufactured duplex stainless steel, J. Mater. Process. Technol., 272 (2019), 58-71, doi:10.1016/j.jmatprotec.2019.05.003

${ }^{19}$ X. T. Li, X. Y. Jiang, Effects of dislocation pile-up and nanocracks on the main crack propagation in crystalline metals under uniaxial tensile load, Eng. Fract. Mech., 212 (2019), 258-268, doi:10.1016/j.engfracmech.2019.03.038

${ }^{20}$ Z. W. Li, Z. X. Wen, S. N. Gu, H. Q. Pei, H. S. Gao, Q. Z. Mao, In-situ observation of crack initiation and propagation in Ni-based superalloy with film cooling holes during tensile test, J. Alloy. Compd., 793 (2019), 65-76, doi:10.1016/j.jallcom.2019.04.139 